\title{
PENDAMPINGAN PEMBUATAN PUPUK ORGANIK CAIR PLUS (POC PLUS)
}

\author{
Haryuni*1, Ratih Dwi Kartikasari $^{2}$, Agus Budiyono ${ }^{3}$, Dwi Susilo Utami ${ }^{4}$, Kusriani Prasetyowati ${ }^{5}$ \\ 1,2,3,4,5 Universitas Tunas Pembangunan Surakarta \\ *e-mail: haryuni.haryuni@lecture.utp.ac.id
}

\begin{abstract}
ABSTRAK
Sumber daya alam yang melimpah baik dari tanaman maupun dari hewan dapat digunakan secara maksimal untuk kegiatan pertanian sehingga meningkatkan pendapatan petani, meningkatkan kualitas dan kuantitas hasil pertanian. Ternak sapi merupakan salah satu hewan yang menghasilkan limbah baik padat maupun cair. Tujuan umum kegiatan pengabdian yaitu memanfaatkan limbah ternak cair secara maksimal, target khusus yang ingin dicapai adalah dapat memanfaatkan limbah ternak khususnya urin sebagai bahan baku pembuatan pupuk organik cair (POC) yang ramah lingkungan. Program ini juga bertujuan untuk bisa memanfaatkan dan mengurangi polusi yang disebabkan oleh kotoran ternak. Sedangkan metode yang digunakan dalam pengabdian pada masyatarakat ini adalah simulasi dan demonstrasi, sedangkan kelompok sasaran adalah petani ternak bertempat di Desa Kwangsan Kecamatan Jumapolo, Kabupaten Karanganyar. Pelaksanaan pendampingan pembuatan POC berjalan lancar, mudah dilakukan secara mandiri melalui demonstrasi. Hasil pengabdian masyarakat diharapkan dapat meningkatkan pengetahuan dan pengalaman memanfaatkan limbah ternak sebagai bahan baku pukuk organik yang ramah lingkungan.
\end{abstract}

Kata kunci: limbah , ternak, urine, poc

\section{ABSTRACT}

Natural resources from plants and from animals can be used optimally for agricultural activities so as to increase farmers' income, improve the quality and quantity of agricultural products. Cattle are one of the animals that produce both solid and liquid waste. The general purpose of service activities is to utilize liquid livestock waste to the maximum, the specific target to be achieved is to be able to utilize livestock waste, especially urine as raw material for making environmentally friendly liquid organic fertilizer (POC). This program also aims to be able to utilize and reduce pollution caused by livestock manure. While the method used in this community service is simulation and demonstration, while the target group is livestock farmers located in Kwangsan Village, Jumapolo District, Karanganyar Regency. The implementation of mentoring in making POC runs smoothly, it is easy to do independently through demonstrations. The results of community service are expected to increase knowledge and experience in utilizing livestock waste as an environmentally friendly organic fertilizer raw material.

Keywords: waste, livestock, urine, poc

\section{PENDAHULUAN}

Desa Kwangsan merupakan salah satu desa yang penduduknya memiliki limbah ternak ternak sapi yang cukup banyak dan belum dimanfaatkan secara maksimal oleh masyarakat tani. Dengan banyaknya limbah ternak ternak tersebut kotorannya juga banyak namun belum diolah dengan maksimal sehingga bertahan lama dan meningkatkan fungsi tanah bagi tanaman. Kotoran ternak berupa feses dan urin mempunyai potensi sebagai pupuk padat dan cair. Pemberian secara bersamaan dapat meningkatkan nutrisi tanah karena kandungan mikroorganisme yang berfungsi sebagai pengurai. Pemberian pupuk organik cair mampu mengembalikan unsur hara tanah, memperbaiki sifat kimia dan biologi tanah tanpa merusak sifat fisik tanah.

Limbah ternak yang berupa feses sapi mengandung nitrogen $(\mathrm{N})$ 2,33\%, Pospor (P) P2O5 0,61 \%, kalium (K) K2O 1,58 \%, calsium (Ca) 1,04 \%, magnesium (Mg) 0,33 \%, mangan (Mn) 179 ppm dan zink (Zn) 70,5 ppm sedangkan urine sapi mengandung air 92\%, N 1,00\%, P 0,2\%, dan K 0,35\% (Sutedjo, 2010). Kandungan nitrogen dan pospor yang tinggi baik pada feses maupun urin menjadikan limbah ternak sapi mampu sebagai penyedia unsur hara bagi 
pertumbuhan dan perkembangan tanaman. Kandungan N dan S pada pupuk organik cair (POC) paling mudah menguap yaitu $\mathrm{N}$ dan $\mathrm{S}$, sehingga tidak bisa disimpan dalam waktu lama.selain menguap kualitasnya menurun. Penurunan kualitas disebabkan adanya kerusakan secara fisiologis, enzimatis dan biologis (Rohani et al., 2016; Sarkono et al., 2019;

Penggunaan pupuk kendang urin memberikan keuntungan bagi peternak dan petani, bagi peternak meningkatkan pendapatan sedangkan sedangkan bagi petani untuk mendukung program pemerintah pertanian berkelanjutan, Selaink keuntungan finansial penggunaan pupuk organik cair (POC) limbah ternak sapi lebih cepat menunjukan hasil yaitu cepat diserap oleh tanaman apabila diukur dari harganyapun relatif murah karena bisa membuat sendiri dan yang tak kalah pentingnya yaitu pupuk yang ramah lingkungan tidak menimbulkan pencemaran lingkungan sehingga sangat tepat sebagai pendukung program pemerintah pertanian berkelanjutan.

Permasalahan masyarakat yang ada di kelompok tani Mulyo di desa Kwangsan yaitu kurangnya ketrampilan dan pengetahuan dalam teknologi pemanfaatan limbah urin sapi yang diolah menjadi pupuk organik cair. Selain masalah utama diatas terdapat beberapa permsalahan yang penting khususnya dalam bidang pertanian antara lain : a) lahan pertanian di desa Kwangsan termasuk lahan marginal, b) penggunaan pupuk kimia cenderung meningkat untuk mendapatkan produk/hasil pertanian yang maksimal, c) bahan dasar POC dari limbah ternak yang berlimpah, d) kurangnya inovasi pemanfaatan limbah ternak karena kurangnya pengetahuan dan ketrampilan anggota kelompok tani, e) belum adanya pihak luar yang membangun kerjasama dan anggota kelompok tani untuk mengembangkan pembuatan POC.

Salah satu bentuk limbah ternak yang tersedia cukup banyak yaitu berbentuk urin. Untuk saat ini di desa Mitra urin sapidan sapi belum dimanfaatkan oleh masyarakat secara maksimal. Berdasarkan analisis situasi dan permasalahan yang dihadapi oleh Mitra kelompok tani maka tim Pengabdian menawarkan solusi yang memungkinkan dan bisa dilaksanakan oleh anggota kelompok tani yaitu a) melakukan sosialisasi pentingnya penanganan limbah ternak untuk kesehatan lingkungan, b) memberikan penyuluhan dan pelatihan mengenai pembuatan POC diharapkan mampu mengurangi ketergantungan penggunaan pupuk kimia, mengurangi biaya usaha tani dan meningkatkan lapangan kerja bagi anggota Mitra dan warga desa Kwangsan, c) memberikan penyuluhan dan pelatihan analisis usaha tani secara sederhana, b) memberikan pelatihan pembuatan modul pembuatan POC, c) pendampingan pembuatan, pengemasan, dan pelabelan POC

\section{METODE}

Pelaksanaan pendampingan pengabdian masyarakat pada tanggal 10 Agustus 2019, di Desa Kwangsan Jumapolo Karanganyar, dilaksanakan dengan praktek secara langsung dengan kelompok tani dan dibantu oleh mahasiswa Fakultas Pertanian UTP Surakarta.

Bahan dan alat yang digunakan, Urin sapi $100 \mathrm{~L}$, empon-empon $15 \mathrm{~kg}$, tetes tebu $1 \mathrm{~L}$, bakteri fermentasi, Ember kapasitas 150 L, pengaduk kayu, botol yang berisi air, selang air, karet pengunci embe

Pelaksanaan dan praktek pembuatan pupuk organik cair dilakukan dengan cara a). menyiapkan ember ukuran $150 \mathrm{~L}$ yang sudah dilubangi untuk memasukkan selang dan dilengkapi dengan tutup serta pengunci dari karet, b) kotoran sapi yang sudah dikumpulkan dimasukkan ke dalam ember, c) mencampur $1 \mathrm{~L}$ tetes tebu dengan $1 \mathrm{~L}$ bakteri fermentasi, kemudian dimassukkan ke dalam ember, d) empon-empon yang telah dipotong-potong kecil ke dalam ember, diaduk rata, e) ember ditutup rapat selang dimasukkan ke dalam ember melalui lubang dan bagian luar dimasukkan ke dalam botol yang sudah berisi air. 


\section{HASIL DAN PEMBAHASAN}

Pupuk organik cair (POC) merupakan limbah ternak sapi yang berperan sebagai penyubur tanaman, POC mengandung bahan organik hewani berbentuk cair penggunaannya dengan cara menyiramkan pada media tanam. Selain mudah dalam aplikasi juga cepat meresap ke tanah dan tanaman, aplikasi secara langsung tidak merusak tanaman. POC melalui proses fermentasi bahan-bahan organik yang berasal dari limbah cair ternak juga bias berasal dari limbah manusia yang kandungan unsur haranya lebih dari satu unsur (Sutedjo. 2002; Andri dkk. 2015; Anastasia. 2015). Penggunaan pupuk organik cair limbah ternak menciptakan jiwa kewirausahaan baru sehingga dapat diperjualbelikan baik di dalam anggota kelompok tani maupun di luar.

Hasil keuntungan penjualan produk pupuk cair organik ini nantinya akan dibagi antara kelompok tani dengan pemilik toko pertanian atau koperasi kelompok tani sesuai dengan surat perjanjian kerjasama yang telah disepakati bersama. Kemudian kelompok tani akan membentuk koperasi yang berfungsi untuk mengelola uang hasil penjualan pupuk cair organik. Dengan dibentuknya koperasi kelompok tani, diharapkan dapat membantu anggota kelompok tani yang membutuhkan dana untuk kegiatan pertanian dapat terpenuhi. Keuntungan terbentuknya dari koperasi kelompok tani petani bunga pinjaman rendah, tanpa jaminan yang mengikat, setiap anggota memperoleh sisa hasil usaha (SHU) setiap tahun (Jasmidi et al., 2018).

Kelompok tani dalam menjalankan usaha koperasi tidak membutuhkan waktu khusus sehingga tidak mengganggu aktivitas rutin bercocok tanam, pengerjaannya fleksibel dan mudah serta tidak membutuhkan keterampilan khusus. Selain mudah, usaha sampingan ini akan meningkatkan perekonomian anggota kelompok tani karena lebih mudah mendapatkan bahan baku, serta modal usaha.

Hasil dari kegiatan Pendampingan Pengabdian Masyarakat ini adalah mitra dapat:

1) Memiliki pengetahuan tentang pembuatan pupuk organic cair.

2) Memiliki pengetahuan cara pengemasan dan pelabelan, yang didampingi oleh tim pengabdian dari Fakultas Pertanian Universitas Tunas Pembangunan Surakarta. Pengemasan produk dilakukan secara steril dan baik sehingga tidak akan merusak kualitas. Pengemasan dan pelabelan dilakukan oleh mitra kelompok tani, namun pendampingan oleh tim pelaksana PKM tetap dilakukan.

3) Melakukan promosi, pemasaran, dan mengatur usaha tanpa biaya. Kegiatan ini mampu meningkatkan kesejahteraan anggota kelompok tani, seperti halnya yang telah dilakukan oleh Fitriana dkk (2017) tentang pemanfaatan tinja menjadi pupuk organik cair (POC) sehingga memberikan dampak positif terhadap perekonomian dan kesejaheraan masyarakat. Pemasaran menjadi kegiatan yang ditekankan dalam setiap pendampingan pengabdian masyarakat yang bekaitan dengan kewirausahaan. Seperti kegiatan pengabdian yang dilakukan oleh Sudarman dan Sunyoto (2016), mereka melakukan pendampingan dalam pemasaran dan manajemen usaha. Pemasaran dapat juga dilakukan dengan mengikuti pameran-pameran yang terkait dengan hasil pertanian. Dalam kegiatan ini,pemasaran dilakukan dengan melakukan promosi baik secara online maupun ofline.

4) Proses pembuatan pupuk organic Cair 

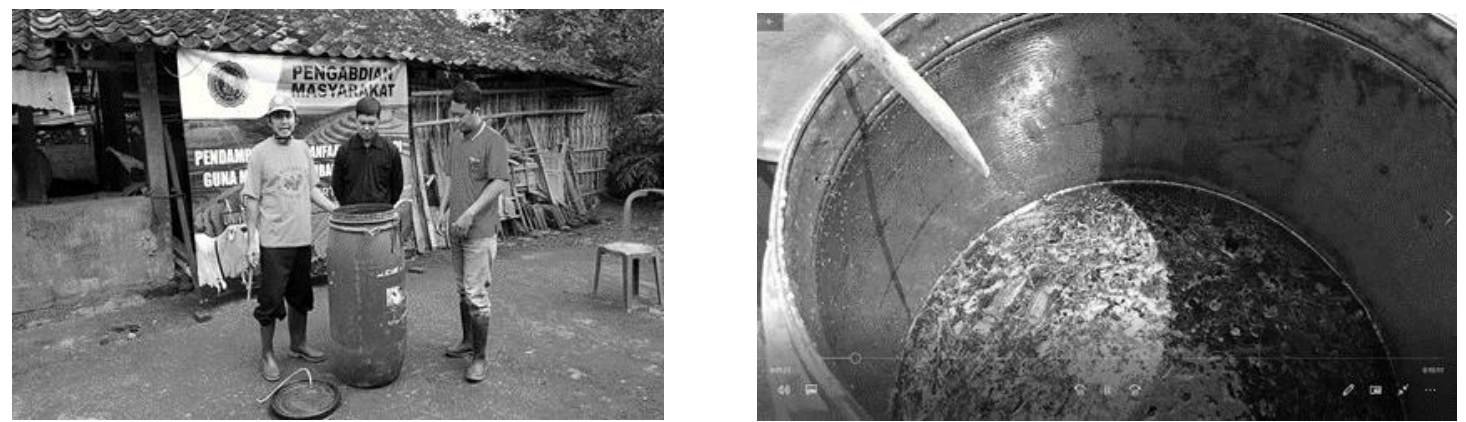

Gambar 1. Persiapan pembuatan POC (a), Limbah ternak sapi (urin) 100 L diaduk rata (b)
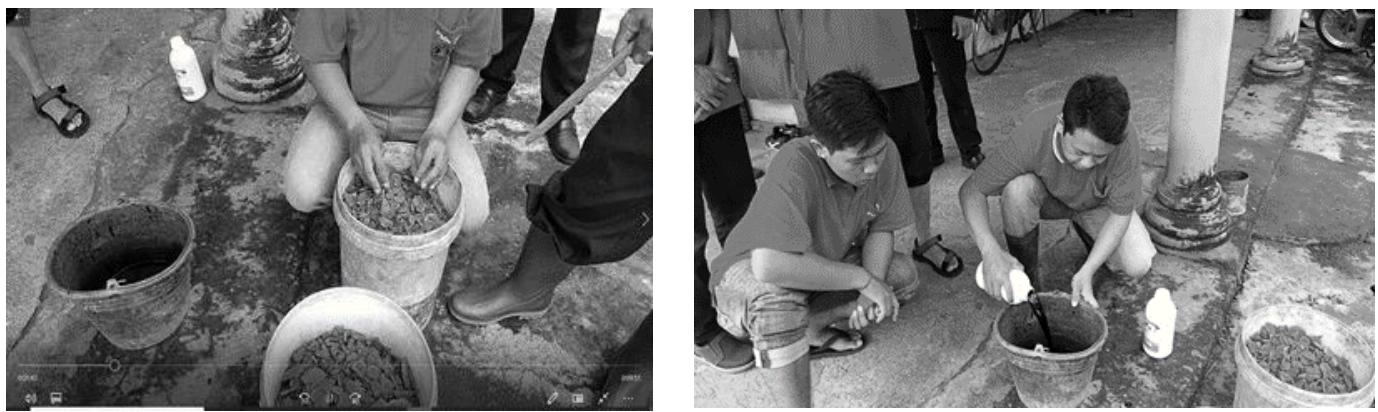

Gambar 2. Mencampur 5 kg empon-empon (a), Menyiapkan $1 \mathrm{~L}$ tetes tebu (b)
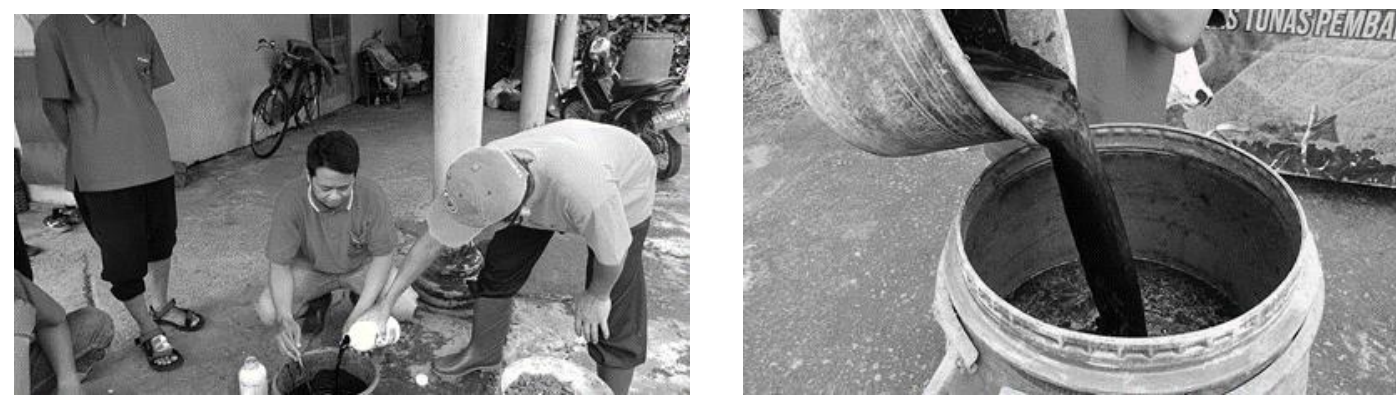

Gambar 3. Mencampur tetes tebu dengan bakteri fermentasi (a), Campuran tetes tebu dan bakteri fermentasi dimasukkan ke dalam ember yang berisi urin (b)
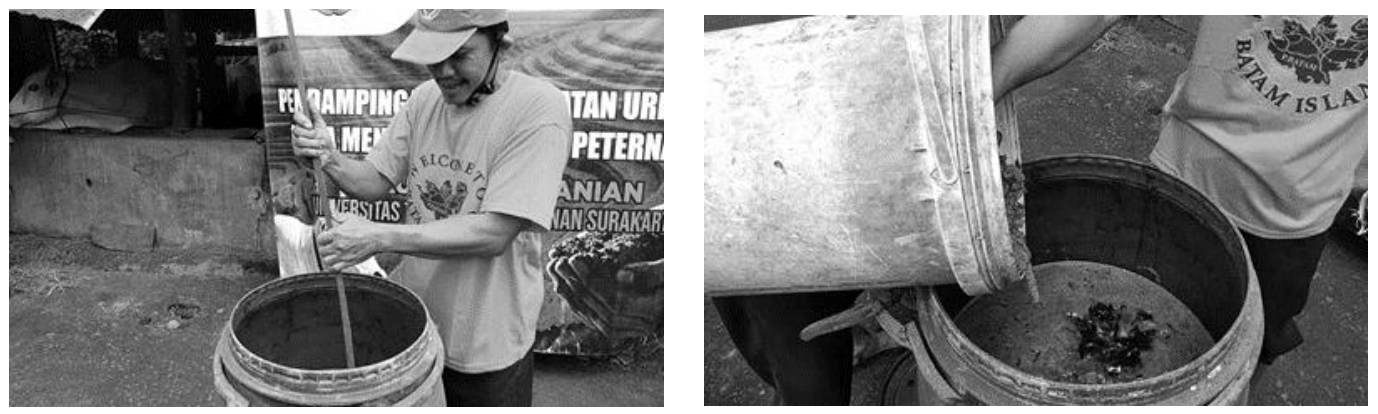

Gambar 4. Campuran urin diaduk rata (a), Menambahkan campuran empon-empon (b) 

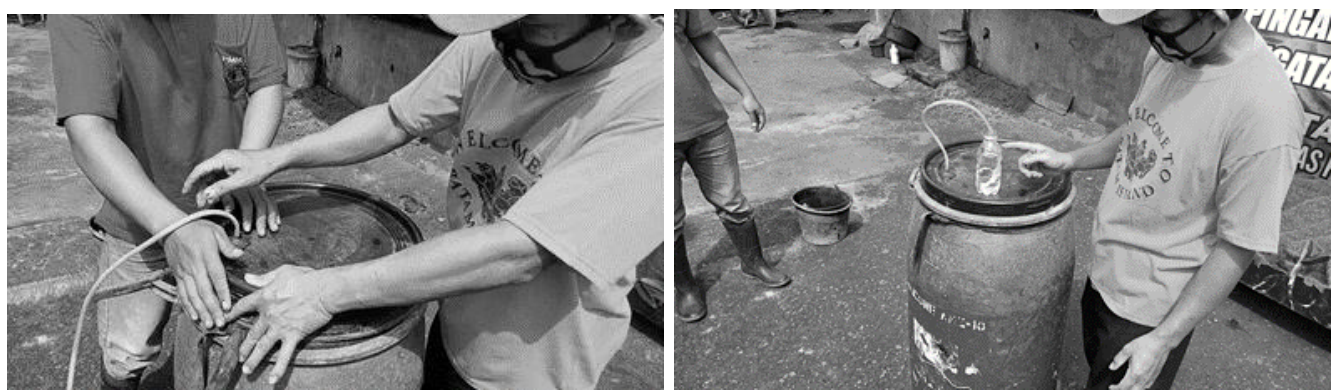

Gambar 5. Ember ditutup rapat selang dimasukkan ke dalam ember (a), Selang dimasukkan ke dalam botol yang berisi air (b)
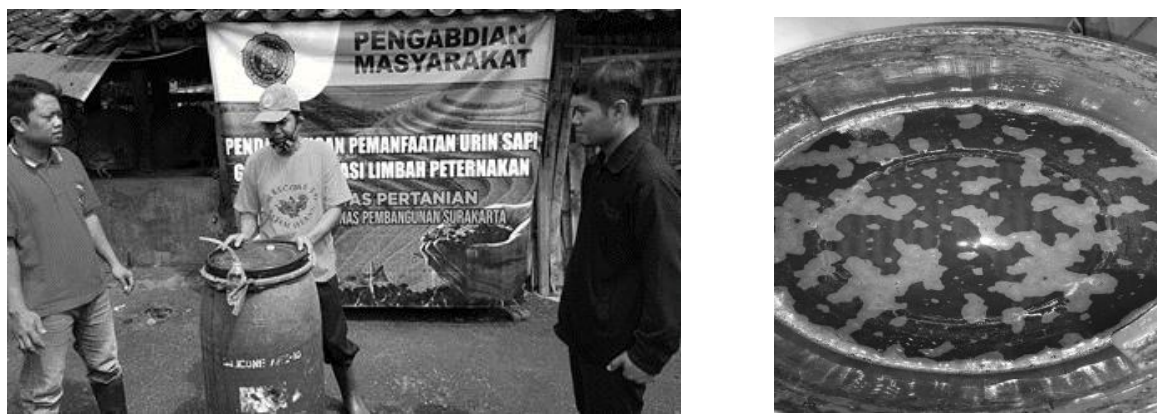

Gambar 6. Fermentasi selama 14-21 hari (a), hasil POC setelah difermentasi 21 hari

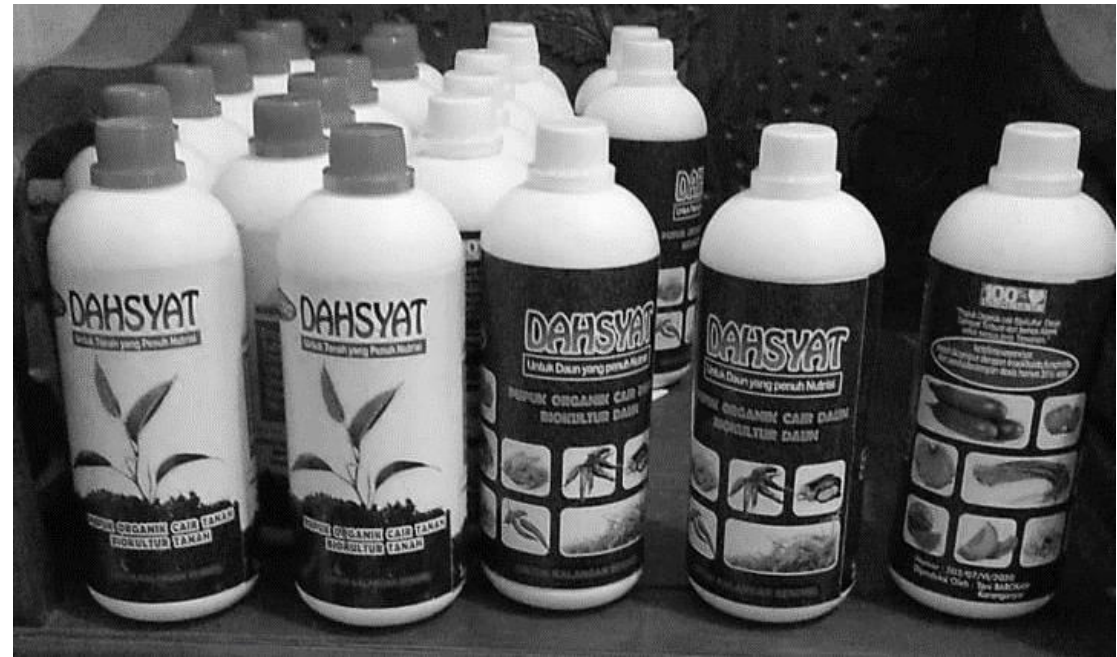

Gambar 7. Pupuk cair yang sudah dikemas dan siap dipasarkan

\section{KESIMPULAN}

Peserta mampu mengaplikasikan materi yang diberikan oleh tim pendampingan kegiatan pengabdian masyarakat, Kegiatan terlaksana dengan lancer tidak ada kendala, POC yang dihasilkan dibagikan ke semua anggota kelompok tani untuk diberikan ke tanaman. Praktek bersama yang dilaksanakan dilanjutkan oleh masing-masing anggota kelompok tani yang memiliki ternak sapi. 


\section{DAFTAR PUSTAKA}

Amilla, Y., 2011, Penggunaan Pupuk organik cair (POC)Untuk Mengurangi Dosis Penggunaan Pupuk Anorganik pada Padi Sawah (Oryza Saliva L.), Laporan Penelitian, Departemen Agronomi dan Holtikultura, Fak. Pertanian, IPB, Bogor.

Anonim. 2019. Cara Mudah Membuat Pupuk organik cair (POC) Urin Sapi. http://kalbar.litbang.pertanian.go.id.

Anastasia R. Moi, dkk. 2015. Pengujian Pupuk organik cair (POC) dari Eceng Gondok(Eichhornia crassipes) Terhadap Pertumbuhan Tanaman Sawi (Brassicajuncea), Jurnal MIPA UNSRAT, 4 (1): 15-19.

Andri, H. Pardosi, dkk. 2015. Respon Tanaman Sawi Terhadap Pupuk Organik CairLimbah Sayuran pada Lahan Kering Ultisol, Prosiding SeminarNasional Lahan Suboptimal, 22 (3).

Devakumar.N., S.Shubha, G.G.E.Rao \& Imrankhan. 2014. Studies on Soil fertility, Cow urine and Panchagavya levels on Growth and Yield of Maize. Rahmann G \& Aksoy U (Eds.) (2014) Proceedings of the 4th ISOFAR Scientific Conference. 'Building Organic Bridges', at the Organic World Congress 2014, 13-15 Oct., Istanbul, Turkey (eprint ID 23358). http://orgprints.org/ Diakses tanggal 20 Maret 2016.

Fitriana, S. dkk. 2017. IbM Pemanfaatan Tinja Menjadi Pupuk Cair Organik di Kelurahan Tambakrejo. E-dimas education. Pengabdian Kepada Masyarakat. Jurnal Pengabdian Kepada Masyarakat Vol 08 (1): 96-103.

Jasmidi, M, Z., \& Prastowo, P. (2018). Pemanfaatan Urin Sapi Menjadi Pupuk Organik Cair Kelompok Tani Desa Sukadamai Timur. Jurnal Pengabdian Kepada Masyarakat, 24(1): 570-575. http://jurnal.unimed.ac.id/2012/index.php/jpkm/article/view/9079

Meena R.P \& Bheemavat B.S, (2009): Moisture use functions and yield of rainfed Maize as influenced by indigenous technologies, Asian Agri-History, 13(2):155-158.

Sudarman, dan Sunyoto. 2016. IbM Kelompok Usaha Tani dan Peternakan. Rekayasa Vol 14 No 1 Juli 2016

Sutedjo, Mul Mulyani. 2002. Pupuk dan Cara Pemupukan. Jakarta: Rineka Cipta. 